\title{
CAlCulating THE INCALCULABLE: PRINCIPLES FOR COMPENSATING IMPACTS to Aboriginal Title
}

\author{
SAM ADKINS, BRYN GRAY, \\ KIMBERLY MACNAB, AND GORDON NETTLETON*
}

\begin{abstract}
There continues to be significant uncertainty over the scope of Aboriginal rights in Canada, which results in significant uncertainty for infrastructure development in the energy sector. Developing a framework for determining fair and reasonable compensation for potential impacts to Aboriginal title is therefore a pressing need for governments as well as proponents. This article explores options on how to ensure greater certainty in the process of determining appropriate compensation for impacts to Aboriginal title. It conducts an analysis of the nature of Aboriginal title, the present compensation methodology for all land types, and the Australian experience with these matters. The article is intended to consider compensation for impacts to Aboriginal title, although it is recognized that impacts to Aboriginal title are not the sole challenges arising from energy infrastructure development in Canada. Also, the proposed framework does not suggest that all infringements to Aboriginal title can be justified with appropriate compensation and there may be situations where no level of payment can compensate for the impact to the community's way of life. The article concludes there are at least three potential approaches to determine appropriate compensation for impacts to Aboriginal title, and regardless of the method chosen all will require extensive reform from the present approach.
\end{abstract}

\section{TABLE OF CONTENTS}

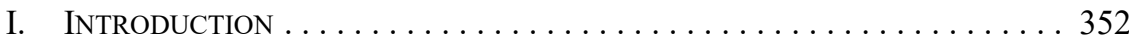

II. AbORiginAL TitLE IN CANADA . . . . . . . . . . . . . . . . . 354

A. Current Aboriginal Title

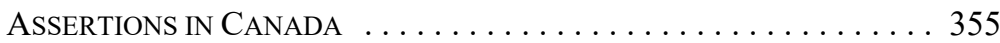

B. DIFFERENCES BETWEEN

Aboriginal Title and Fee Simple $\ldots \ldots \ldots \ldots \ldots \ldots \ldots \ldots$

C. Duty to CONSUlt AND ACCOMMOdATe,

AND TITLE INFRINGEMENTS $\ldots \ldots \ldots \ldots \ldots \ldots \ldots \ldots \ldots \ldots \ldots$

III. CANADIAN PRocesses AND PRINCIPLES of COMPENSATION . . . . . . 360

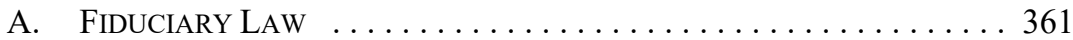

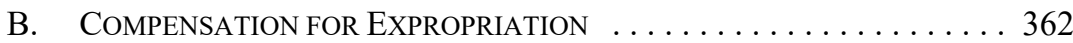

C. EXPROPRIATION UNDER MODERN TREATIES . . . . . . . . . 365

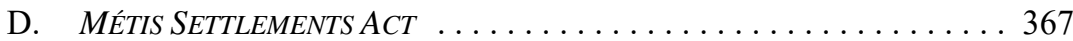

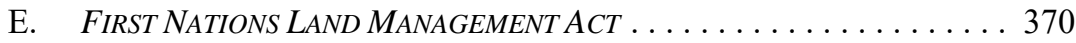

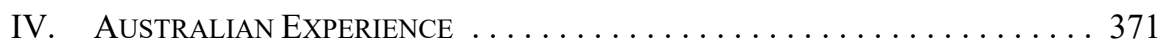

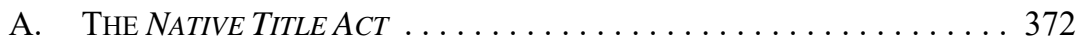

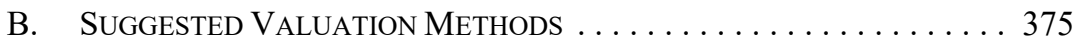

C. INDIGENOUS LAND USE AND

IMPACT BENEFIT AGREEMENTS $\ldots \ldots \ldots \ldots \ldots \ldots \ldots \ldots \ldots$

Gordon Nettleton and Bryn Gray are partners, and Kimberly Macnab is an associate, at McCarthy Tétrault LLP. Sam Adkins is the Aboriginal Relations Manager for LNG Canada and was previously a partner at McCarthy Tétrault LLP. The authors would like to acknowledge the assistance of Beverly Ma in the research and editing of this article. The Canadian Energy Law Foundation does not necessarily endorse the contents or the opinions presented in this article. 


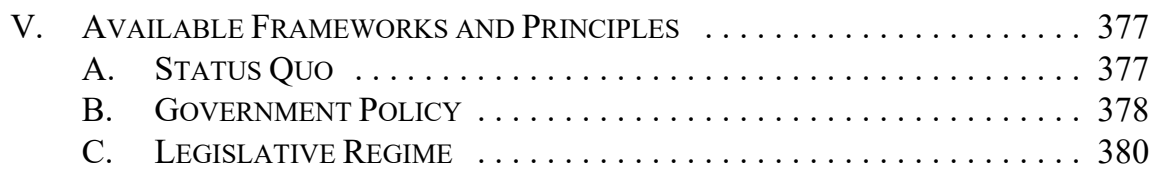

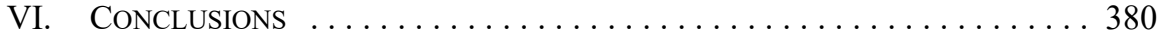

\section{INTRODUCTION}

Ultimately, it is through negotiated settlements, with good faith and give and take on all sides, reinforced by the judgments of this Court, that we will achieve what [was] stated in Van der Peet, to be a basic purpose of s. 35(1) - "the reconciliation of the pre-existence of aboriginal societies with the sovereignty of the Crown". Let us face it, we are all here to stay. ${ }^{1}$

The Supreme Court of Canada has repeatedly emphasized that the long road of reconciliation between Aboriginal and non-Aboriginal Canadians requires good faith and give-and-take on all sides to reach negotiated settlements, with litigation as a last resort. This has, however, proven to be easier said than done. Negotiations to resolve outstanding claims with respect to asserted Aboriginal rights typically move at a glacial pace, and many Aboriginal groups with unsettled rights assertions are not participating in the existing negotiating frameworks for various reasons. As a result, there continues to be significant uncertainty and disagreement over the nature and scope of Aboriginal rights in many parts of Canada, which in turn causes significant uncertainty for energy infrastructure development.

Many industry proponents have been successful in building relationships with Aboriginal groups, and obtaining their support for proposed projects through modifications designed to minimize impacts and agreements that share a range of economic and other benefits from their projects. However, in many other cases, agreements are not reached for a variety of reasons. One of the most challenging situations in negotiations between Aboriginal groups and industry proponents is where there is a strong case for Aboriginal title and the expectation of significant "economic accommodation." 2 The current process for addressing this is ad hoc, with no rules other than the basic precept of negotiation: "to what can the parties agree?"

The stakes in this area have been raised by Supreme Court's historic declaration of Aboriginal title in Tsilhqot'in Nation v. British Columbia ${ }^{3}$ and the commitments of the federal and Alberta governments to implement the United Nations Declaration on the Rights of Indigenous Peoples ${ }^{4}$ and with it the principle of free, prior, and informed consent (FPIC). As explored in this article, the circumstances in which Canadian law requires consent remain limited. Nevertheless, these developments have heightened expectations amongst Aboriginal groups for consent-based decision-making, including related issues of compensation, and

Delgamuukw v British Columbia, [1997] 3 SCR 1010 at para 183 [Delgamuukw] [references omitted], citing $R v$ Van der Peet, [1996] 2 SCR 507 at para 31 [Van der Peet].

There is some jurisprudential uncertainty regarding whether economic accommodation is payable, and there are concerns with the concept that monetary compensation can constitute sufficient accommodation depending on the situation: see Part II.C.1, below. 2014 SCC 44, [2014] 2 SCR 257 [Tsilhqot'in].

GA Res 61/295, UNGAOR, 61st Sess, Supp No 53, UN Doc A/RES/61/295 (2007) [UNDRIP]. 
created additional uncertainty about what is required for industry proponents. In practice, increased government scrutiny of resource projects that may impact Aboriginal title means that seeking consent (if not achieving it) is quickly becoming the standard for these projects to proceed in Canada.

But what if consent cannot be obtained? Canadian law does not require consent prior to the establishment of Aboriginal title. Even when Aboriginal title is proven, consent is not always attainable, and "justifiable" infringements of established Aboriginal title are permissible provided the Crown has met its legal obligations, which generally entails an assessment of whether appropriate compensation has been offered. The provision of adequate compensation may also become relevant in cases of strong assertions of Aboriginal title, given the interest of both governments and proponents in insulating project authorizations from subsequent determinations of Aboriginal title. ${ }^{5}$ As a result, developing a framework for determining fair and reasonable compensation for impacts to Aboriginal title is an increasingly pressing need for both governments and proponents.

This article considers how to inject greater certainty into the process of determining appropriate compensation for impacts to Aboriginal title lands. Specifically, we consider whether certain existing processes and methods of calculating impacts to land rights may provide guidance in developing a set of principles for calculating the quantum of compensation for infringements of established Aboriginal title, and potentially for any required economic accommodation for unavoidable impacts to strong claims of Aboriginal title. ${ }^{6}$ In pursuit of this objective, we provide a comparative analysis of: (1) the nature of Aboriginal title, including a comparison to fee simple title; (2) existing land compensation processes and principles in Canada for fee simple, treaty settlement lands, and lands subject to Aboriginal interests; and (3) the Australian experience with compensation for impacts to Aboriginal title. $^{7}$

Our analysis is limited to considering compensation for impacts to Aboriginal title. While we recognize the broader challenge of addressing impacts to, or infringements of, other Aboriginal and treaty rights arising from energy infrastructure development in Canada, we have limited this article to Aboriginal title for a number of reasons. First, it is currently the most significant area of uncertainty for industry proponents, governments, and Aboriginal groups. Second, the economic component of Aboriginal title has been described by courts as an ownership interest that, when interfered with, will typically give rise to a right of compensation. Third, if economic accommodation is indeed required at law for impacts to asserted but yet unproven Aboriginal rights, it will surely be most relevant to strong Aboriginal title claims given the economic component of title (rather than other asserted Aboriginal rights, which may be more readily addressed through traditional accommodation

In Tsilhqot'in, supra note 3, the Supreme Court of Canada created some uncertainty on this point by stating that the Crown may have to revisit project approvals if Aboriginal title is subsequently established, and continuing the project would be "unjustifiably infringing" (ibid at para 92).

For ease of reference in this article, we will use the term "compensation for impacts to Aboriginal title" to refer to compensation for both infringements of established Aboriginal title and impacts to strong claims of asserted Aboriginal title.

Australian legal tradition consistently refers to indigenous persons and groups as "natives," and indigenous title claims as "native title." However, for the sake of consistency, this article will refer to Australian "native title" as "Aboriginal title." This usage does not, however, suggest that these concepts are identical. 
measures such as avoidance or mitigation of impacts). Fourth, Aboriginal title offers a more useful comparator to fee simple title and indigenous interests in other jurisdictions, compared to other Aboriginal or treaty rights, which can vary significantly in content and scope. In any event, we believe that the principles discussed in this article will also provide guidance, subject to modification, to consider compensation principles in cases of infringements or impacts to other Aboriginal and treaty rights, if compensation is required in the circumstances.

Finally, while the discussion in this article is focused on developing a framework for compensating impacts to Aboriginal title, this should not be construed as suggesting that all infringements to Aboriginal title can be justified with appropriate compensation, regardless of the impacts. Indeed, there may be situations where no level of compensation is sufficient because the Aboriginal interest is so significant to the way of life of the community that the impact outweighs the broader public interest. Compensation is ultimately only one of the factors the Crown must consider in justifying infringements of Aboriginal title.

\section{Aboriginal Title in Canada}

In 1982, the Aboriginal and treaty rights of First Nations, Metis, and Inuit peoples in Canada became constitutionally protected through the enactment of section 35 of the Constitution Act, $1982 .{ }^{8}$ While this significantly increased the protection of Aboriginal and treaty rights in Canada, the Supreme Court of Canada has recognized that these rights are not absolute and can be infringed by the Crown if certain requirements are met. ${ }^{9}$

There is a broad range of asserted and established Aboriginal rights in Canada. The most significant is Aboriginal title, which is a sui generis right in land that is distinct from other proprietary interests such as fee simple estates. ${ }^{10}$ It is unique in its source, the way it is proven, and the rights and limitations conferred once it is established.

Aboriginal title arises from the possession and occupation of lands by Aboriginal peoples living in Canada before the arrival of the Europeans. This is in contrast to fee simple interests, which were granted by the Crown following the assertion of sovereignty. ${ }^{11}$ The Supreme Court has held that "Aboriginal title is a burden on the Crown's underlying title," 12 and that the doctrine of terra nullius (that no one owned the land pre-assertion of sovereignty) does not apply in Canada. ${ }^{13}$ The Supreme Court has also held that the sui generis nature of Aboriginal title requires that it be approached from both the common law and Aboriginal perspectives, including pre-existing systems of Aboriginal law. ${ }^{14}$ This dual perspective approach influences the way in which Aboriginal title is proven and the bundle of rights that Aboriginal title confers once it is established. 
In Delgamuukw and Tsilhqot'in, the Supreme Court held that three criteria must be met to establish Aboriginal title: (1) sufficient pre-sovereignty occupation; (2) continuous occupation (where present occupation is relied upon as proof of pre-sovereignty occupation); and (3) exclusive occupation of the land at the time of sovereignty. ${ }^{15}$ These criteria are not watertight compartments that must be considered independently, but rather, provide a lens through which to determine whether Aboriginal title is established. In Tsilhqot'in, the Supreme Court cautioned that "the court must be careful not to lose or distort the Aboriginal perspective by forcing ancestral practices into the square boxes of common law concepts, thus frustrating the goal of faithfully translating pre-sovereignty Aboriginal interests into equivalent modern legal rights." 16

To date, there has only been one declaration of Aboriginal title by Canadian courts, in Tsilhqot'in. ${ }^{17}$ Beyond the historic nature of this declaration, Tsilhqot'in clarified how to determine the sufficiency of pre-sovereignty occupation in a way that could make it easier for some Aboriginal groups to establish title to larger tracts of land. The Supreme Court indicated that Aboriginal title is not limited to specific village sites or areas of intensive use; rather, title can be established through regular use of lands for trapping, hunting, fishing, and foraging, provided the use "evinces an intention on the part of the Aboriginal group to hold or possess the land in a manner comparable to what would be required to establish title at common law."18 This is based on the need to consider both the common law test for possession and the perspective of the Aboriginal group using a "culturally sensitive approach to sufficiency of occupation." 19

\section{A. Current Aboriginal Title ASSERTions in CANADA}

The majority of Aboriginal title assertions in Canada are in British Columbia, and most of these assertions have some degree of overlap with the assertions of other Aboriginal groups in the province. In addition, there are unsettled Aboriginal title claims across Canada, including claims in the North, Alberta, Ontario, Quebec, Atlantic Canada, and Manitoba. Some of these claims also include assertions of Aboriginal title to water beds or bodies of water, an issue that to date has not been judicially considered in Canada. ${ }^{20}$

Ibid at para 143; Tsilhqot'in, supra note 3 at paras 25-26, 45, 47.

Tsilhqot'in, ibid at para 32.

In Tsilhqot'in, the Supreme Court of Canada recognized Aboriginal title to 1750 square kilometres of Crown land in West-Central British Columbia. This case had a number of key distinguishing features from other Aboriginal title assertions, including that there were no overlapping claims by other Aboriginal groups, and there was evidence that the Tsilhqot'in demanded outsiders seek permission to pass over their land, and removed trespassers from their land. Further, the land was extensive but harsh, and capable of supporting only 100 to 1,000 people. This was relevant for the ability of this small group, comprised of approximately 400 people at the time, to exercise effective control and sufficient occupation (ibid at paras 37,58 ).

Ibid at para 42 .

19 Ibid at para 41. See also $R v$ Marshall; $R v$ Bernard, 2005 SCC 43, [2005] 2 SCR 220 [Marshall], citing Delgamuukw, supra note 1 (the Court will focus on the occupation and use of the land as part of the Aboriginal society's traditional way of life).

20 For example, the Council of Haida Nation claim Aboriginal title to the waters surrounding Haida Gwaii, the Gitga'at First Nation claim Aboriginal title to portions of the Douglas Channel in British Columbia, the Saugeen Ojibway Nation claim Aboriginal title to portions of Lake Huron and Georgian Bay waterbeds, and the Mohawks of Akwesasne claim Aboriginal title to the waterbed of the St Lawrence Seaway. 
Although there are Aboriginal title assertions throughout Canada, in many areas of the country Aboriginal title has been surrendered or modified pursuant to treaty, such as the claims of Aboriginal signatories to the 26 modern treaties and the 11 historic numbered treaties. These treaties and other historic treaties with land surrender provisions cover northern Quebec, much of Ontario, Manitoba, Saskatchewan, Alberta, portions of British Columbia, Nunavut, and large portions of the Yukon and Northwest Territories. Aboriginal title assertions are nonetheless relevant for certain historic treaties, including the numbered treaties, as some Aboriginal groups challenge the validity of the land surrender provisions, ${ }^{21}$ dispute the boundaries of the treaty, or argue that they are not treaty signatories. ${ }^{22}$

\section{B. DIFFERENCES BETWEEN \\ Aboriginal Title and Fee Simple}

Aboriginal title confers a broad bundle of rights similar to fee simple, including "the right to decide how the land will be used; the right of enjoyment and occupancy of the land; the right to possess the land; the right to the economic benefits of the land; and the right to proactively use and manage the land." 23 The use of Aboriginal title lands is not limited to how Aboriginal groups used the land prior to the assertion of sovereignty. ${ }^{24}$ However, there are three important restrictions on Aboriginal title which ensure continuity of the Aboriginal group's relationship with the land: (1) the land must be collectively held; (2) the land cannot be alienated except to the Crown; and (3) the land cannot be encumbered, developed, or "misused in a way that would substantially deprive future generations of the benefit of the land.",25

Although the third restriction could be a very significant limitation, it has received no judicial consideration to date. However, the Supreme Court of Canada held in Delgamuukw that it must be considered through the lens of the relationship that the particular group has to the land at issue. The Supreme Court highlighted examples of potential irreconcilable uses, such as strip mining a traditional hunting ground, or converting land of ceremonial and cultural significance into a parking lot. ${ }^{26}$

\section{Duty to Consult ANd ACCommodate, AND TITLE INFRINGEMENTS}

Both asserted and established Aboriginal title claims can create significant uncertainty for resource development due to the lack of clarity on what may be required for consultation and accommodation. The Crown has a duty to consult and potentially accommodate affected Aboriginal groups whenever it contemplates conduct that may adversely impact asserted or

Several southern Alberta First Nations are currently seeking a declaration of Aboriginal title and rights over land covered by Treaty 7 , and there are several First Nations in northern Ontario challenging the taking-up clause in Treaty 9 . The basis of both challenges is that the treaties do not reflect the oral agreement between the parties.

For example, there are eight Ojibway First Nations in Ontario seeking a declaration of Aboriginal title to lands on the north shore of Lake Superior, claiming that they are not parties to the Robinson-Superior Treaty of 1850 .

Tsilhqot'in, supra note 3 at para 73 .

Delgamuukw, supra note 1 at para 117; Tsilhqot'in, ibid at para 15.

Tsilhqot'in, ibid at paras 73-74.

Delgamuukw, supra note 1 at para 128. 
established Aboriginal and treaty rights, including Aboriginal title. ${ }^{27}$ While the duty is owed by the Crown, governments may delegate procedural aspects of the duty to consult to industry proponents. In practice, governments rely heavily on industry for consultation and accommodation. $^{28}$

The level of consultation required in a given situation is contextual and proportionate to a preliminary assessment of the strength of the claim and the seriousness of the potential impact of the proposed government action on the right claimed. ${ }^{29}$ Although this may seem straightforward, it has led to many disputes between Aboriginal groups, industry proponents, and governments about the degree of consultation and accommodation required in a given case. Regardless of the level of consultation required, the courts have repeatedly emphasized that consultation must be meaningful and conducted in good faith. Aboriginal groups also have reciprocal obligations to participate in good faith and cannot frustrate reasonable good faith efforts by imposing unreasonable conditions or refusing to participate. ${ }^{30}$

\section{ECONOMIC ACCOMMODATION PRIOR TO ESTABLISHING TITLE}

Good faith consultation may reveal a duty to accommodate, particularly where there is a strong prima facie case for Aboriginal rights or title and the potential for significant impacts on asserted or established Aboriginal or treaty rights. Accommodation typically involves taking steps to avoid irreparable harm, or mitigating the effects of a government action or decision on the Aboriginal interests at stake. Accommodation is not a substantive right and will not be required in all instances; what is necessary accommodation in a given case is factspecific. ${ }^{31}$ There is no duty to agree, nor is there an Aboriginal veto prior to the establishment of Aboriginal title. ${ }^{32}$

To date, the case law has not clearly defined whether the outcome of the consultation process may impose on the Crown an obligation to financially compensate Aboriginal groups for impacts on asserted but yet unproven rights (commonly referred to as "economic accommodation"). While some industry proponents and governments provide economic accommodation for impacts on asserted rights in certain circumstances, the question of whether this forms part of the legal obligation of accommodation has been treated inconsistently by the courts. In Ka'a'Gee Tu First Nation v. Canada (Attorney General) et al., Justice de Montigny of the Federal Court of Canada stated:

Aboriginal title undoubtedly entails an ownership interest and a correlative right to compensation for interference with that interest. It does not follow, however, that prior to the determination of title,

Haida Nation v British Columbia (Minister of Forests), 2004 SCC 73, [2004] 3 SCR 511 at para 35 [Haida]; Taku River Tlingit First Nation v British Columbia (Project Assessment Director), 2004 SCC 74, [2004] 3 SCR 550 at para 25 [Taku River]; Mikisew Cree First Nation v Canada (Minister of Canadian Heritage), 2005 SCC 69, [2005] 3 SCR 388 [Mikisew Cree].

Haida, ibid at para 53.

Ibid at para 35; Taku River, supra note 27 at para 25, Mikisew Cree, supra note 27 at para 63.

Haida, ibid at para 42; Canada (Attorney General) v Long Plain First Nation, 2015 FCA 177, 388 DLR (4th) 209 at para 158.

Beckman v Little Salmon/Carmacks First Nation, 2010 SCC 53, [2010] 3 SCR 103 at para 14.

Haida, supra note 27 at para 45; Mikisew Cree, supra note 27 at para 66; Yellowknives Dene First Nation v Canada, 2015 FCA 148, 474 NR 350 at para 56. 
consultations must include meaningful discussions and accommodation of the impacts to the economic component of that title. As Hall J.A., of the British Columbia Court of Appeal, stated in Musqueam Indian Band v British Columbia (Minister of Sustainable Resource Management), 2005 BCCA 128 at para 97, 251 $\operatorname{DLR}$ (4th) 717 “...it is too early to be at all categorical about the ambit of appropriate accommodative solutions that have to work not only for First Nations people but for all of the populace having a broad regard to the public interest.",33

In Ka'a'Gee, Justice de Montigny further commented that the duty to consult is not intended to provide Aboriginal groups "immediately with what they could be entitled to, if and when they prove their claims or settle them through treaty." ${ }^{34}$ Rather, the duty to consult is "a means to ensure that the land and the resources that are the subject of the negotiations will not have been irremediably depleted or alienated by the time an agreement is reached." 35

In contrast, in Musqueam, Justice Hall of the British Columbia Court of Appeal acknowledged the possibility that "some species of economic compensation" 36 could be an appropriate measure of interim accommodation for the claim at issue, which was over longestablished, built-up land in the middle of Vancouver. However, in his concurring reasons, Justice Lowry stated that Justice Hall's commentary on financial compensation as appropriate interim accommodation should be "put to one side for now." ${ }^{37}$ Justice Lowry commented instead that case law provides little assistance in determining interim accommodation and that where Aboriginal title had not yet been established, there may well be "questions about whether and to what extent economic compensation or other forms of what might be said to be non-reversible accommodation are necessary or appropriate." 38

\section{CONSENT Prior to Establishing Title}

Consent for development that may impact asserted Aboriginal title is not legally required prior to the establishment of title; however, two recent developments have created some uncertainty in this respect. First, the Supreme Court of Canada indicated in Tsilhqot'in that governments may be required to cancel projects if: (1) they were approved without consent; (2) Aboriginal title is subsequently established; and (3) the continuation of the project unjustifiably infringes such title:

Once title is established, it may be necessary for the Crown to reassess prior conduct in light of the new reality in order to faithfully discharge its fiduciary duty to the title-holding group going forward. For example, if the Crown begins a project without consent prior to Aboriginal title being established, it may be required to cancel the project upon establishment of the title if continuation of the project would be unjustifiably infringing. Similarly, if legislation was validly enacted before title was established, such legislation may be rendered inapplicable going forward to the extent that it unjustifiably infringes Aboriginal title. ${ }^{39}$

FC 297, 406 FTR 229 at para 121 [Ka'a'Gee] [emphasis added]. See also Musqueam Indian Band $v$ Minister of Sustainable Resource Management et al, 2005 BCCA 128, 251 DLR (4th) 717 [Musqueam].

Ka'a'Gee, ibid at para 123.

Ibid.

Musqueam, supra note 33 at paras 98, 100; the British Columbia Court of Appeal released separate written reasons by Justices Southin, Hall, and Lowry, concurring in allowing the appeal.

Ibid at para 104.

Ibid at 105.

Tsilhqot'in, supra note 3 at para 92 . 
Second, the federal and Alberta governments have specifically committed to implementing UNDRIP, which obliges states to obtain FPIC from Aboriginal groups in a number of situations, including the "approval of any project affecting their lands or territories and other resources. $" 40$ The premiers of each of the provinces and territories have also indirectly pledged to implement UNDRIP as a result of their joint commitment in July 2015 to fully implement all 94 recommendations of the Truth and Reconciliation Commission (which included a recommendation to implement UNDRIP). Although Canadian courts to date have held that UNDRIP is not legally binding in Canada and does not alter the current law on the duty to consult, it remains to be seen how governments in Canada will implement UNDRIP and more specifically FPIC. ${ }^{41}$ Recent statements by the Honourable Carolyn Bennett, Minister of Indigenous and Northern Affairs Canada, suggests that Canada's implementation of FPIC may not significantly diverge from the current law on consultation and accommodation, whereby obtaining consent will be the objective of any consultation process but not an absolute requirement, except in limited circumstances like established Aboriginal title. ${ }^{42}$

\section{JUSTIFICATION FOR INFRINGEMENT}

Once Aboriginal title has been established, the Crown must seek the consent of the respective Aboriginal group for use of or developments on the land. The Crown can only proceed without consent if it can justify the infringement. While not all impacts to Aboriginal rights will constitute infringements, the Supreme Court of Canada has held that any use of Aboriginal title lands without consent constitutes an infringement. ${ }^{43}$

Justification for infringement requires the Crown to show that:

- $\quad$ it complied with its procedural duty to consult and accommodate;

- the action is backed by a compelling and substantial legislative objective; and

$40 \quad$ UNDRIP, supra note 4, art 32(2).

$41 \quad$ Nunatukavut Community Council v Canada, 2015 FC 981, 96 CELR (3d) 211 at para 104; Hupacasath First Nation v Canada (Minister of Foreign Affairs), 2013 FC 900, 438 FTR 210 at 51; Gitxaala Nation $v$ Canada, 2015 FCA 73, 2015 FCA 73 (CanLII) at para 16.

42 "Fully Adopting UNDRIP: Minister Bennett's Speech at the United Nations," Northern Public Affairs (11 May 2016), online: <www.northernpublicaffairs.ca/index/fully-adopting-undrip-minister-bennettsspeech >; "Canada and UNDRIP: Q\&A with Minister Bennett's Office," Northern Public Affairs (28 April 2016), online: <www.northernpublicaffairs.ca/index/canada-and-undrip-qa-with-minister-bennettsoffice $>$. For a further discussion about Canada's endorsement of UNDRIP and potential considerations relevant to Canada's implementation of UNDRIP, see Stephanie Axmann et al, "Canada Announces Unqualified Support for UNDRIP: Suggests Canada's Existing Constitutional Obligations Serve to Fulfil the Principles of 'Free, Prior and Informed Consent," Canadian ERA Perspectives (11 May 2016), online: $<$ www.canadianeraperspectives.com $/ 2016 / 05 /$ hec canada-announces-unqualified-support-forundrip-suggests-canadas-existing-constitutional-obligations-serve-to-fulfil-the-principles-of-free-priorand-informed-consent/>; Stephanie Axmann \& Bryn Gray, "The United Nations Declaration on the Rights of Indigenous Peoples and Free, Prior and Informed Consent: Where Does Canada Go From Here?" Mining in the Courts (March 2016), vol 6 at 6, online: $<$ mccarthy.ca/pubs/Mining_in_the Courts 2016 DIGITAL.PDF>.

43 Infringement in the context of Aboriginal rights requires a meaningful diminution of the right, which must take into account the characteristics and incidents of the right at issue. See Sparrow, supra note 9; Tsilhqot'in, supra note 3 at para 122; Grassy Narrows First Nation v Ontario (Natural Resources), 2014 SCC 48, [2014] 2 SCR 447 at para 52. 
- the government action is consistent with the Crown's fiduciary duty to the Aboriginal group, which requires that:

- the incursion on Aboriginal title does not substantially deprive future generations of the benefit of the land;

- the incursion is necessary to achieve the Crown's objective; ${ }^{44}$

- the Crown is going no further than necessary to achieve it; and

- the benefits that may be expected to flow from the objective are not outweighed by adverse effects on the Aboriginal interest. ${ }^{45}$

To date, there has been no decision in which the courts have determined whether an infringement of Aboriginal title was justified under this test. ${ }^{46}$ However, the Supreme Court has indicated that fair compensation will typically be required when Aboriginal title is infringed, and that the amount of compensation payable will vary based on the nature of the particular Aboriginal title affected, the nature and severity of the infringement, and the extent to which Aboriginal interests were accommodated. ${ }^{47}$

\section{Canadian Processes AND PRINCIPLES OF COMPENSATION}

The framework articulated by the Supreme Court of Canada presents unique challenges associated with developing principles designed to determine appropriate compensation for impacts to Aboriginal title. Any such principles presumably must take into account both the common law and Aboriginal perspectives, and cannot be unilaterally developed or imposed. A workable approach will require active participation of Aboriginal groups in formulating and modifying principles, as well as deep consultation with the affected Aboriginal group. While the challenges are unique, both the common law and existing legal frameworks can be instructive in developing such a set of principles and are arguably what courts would look to if asked to determine this issue. Canadian law has a long history of resolving conflicting rights, valuing intangible interests, and developing principles to balance the interests of different segments of society.

Former Chief Justice Lamer held that the range of objectives that can justify the infringements of Aboriginal title could in principle include "the development of agriculture, forestry, mining, and hydroelectric power, the general economic development of the interior of British Columbia, protection of the environment or endangered species, the building of infrastructure and the settlement of foreign populations to support those aims" (Delgamuukw, supra note 1 at para 165).

45 Tsilhqot'in, supra note 3 at paras $80-86$.

46 Peter W Hogg \& Daniel Styler, "What Counts as Justification under Section 35?" (Paper delivered at the Ontario Bar Association Institute 2015 Aboriginal Law Program, Toronto, 5 February 2015), in Renée Pelletier \& Patrick G Duffy, eds, Aboriginal Law: The Buzz in Aboriginal Law - Hot Topics, Emerging Issues \& ... Gamer Changers? (Toronto: Ontario Bar Institute, Association's Institute, 2015), Tab 1 .

47 Delgamuukw, supra note 1 at para 169. 


\section{A. FIDUCIARY LAW}

Canadian judicial consideration of Aboriginal interests in land has been grounded in principles of fiduciary law. In the Supreme Court of Canada's seminal decision in Guerin v. The Queen, the nature of Aboriginal title, and the framework of the statutory scheme established for the purposes of disposing of lands under the Indian Act, were considered to place an equitable obligation upon the Crown to deal with the land for the benefit of Aboriginal peoples. ${ }^{48}$ According to the Supreme Court, where an Indian Band surrenders its interest in land to the Crown (as was the case in Guerin), a fiduciary obligation takes hold, and the Crown must act in accordance with that obligation in dealing with the land. ${ }^{49}$

In An Overview of Aboriginal and Treaty Rights and Compensation for their Breach, now Justice Robert Mainville of the Quebec Court of Appeal concluded that compensation for breaches and infringements of Aboriginal and treaty rights, including Aboriginal title, should be rooted in the principles governing damages for breach of fiduciary duty rather than principles of fair compensation for expropriation. ${ }^{50}$ This was based on his assessment of the frailties of expropriation law in dealing with land for which there is no readily ascertainable market value. ${ }^{51}$ Mainville suggested that the use of fiduciary law enables courts to fashion more flexible remedies, particularly restitutionary remedies and constructive trusts, and that monetary compensation may be awarded in addition to these remedies. ${ }^{52}$ He posited that determining such compensation should take into account principles applicable to breach of fiduciary duty, including "compensation equivalent to full restitution and disgorgement of benefits, compensation for lost opportunities, and compensation for injurious affection and consequential damages." ${ }^{53}$

Mainville suggests six "simple but comprehensive" legal principles for determining compensation:

A. compensation is to be determined in accordance with a methodology that takes into account the principles of fiduciary law;

B. relevant factors in determining compensation include the impacts on the affected Aboriginal community and the benefits derived by the Crown and third parties from the infringement;

Guerin v R, [1984] 2 SCR 335 [Guerin]; Indian Act, RSC 1985, c I-5.

Guerin, ibid at 385 .

Robert Mainville, An Overview of Aboriginal and Treaty Rights and Compensation for their Breach (Saskatoon: Purich, 2001) at 87,94. Principles of compensation examined by Mainville include market value, potential value and special adaptability, intrinsic value and equivalent reinstatement, and consequential impacts and injurious affection. Mainville notes, however, that market value alone "fails to capture many important considerations that need to be taken into account when dealing with Aboriginal issues" and provides little guidance in areas without comparable properties (ibid at 93-94). For the authoritative expropriation text in Canada, see John A Coates \& Stephen F Waqué, New Law of Expropriation (Toronto: Carswell, 1986) at 33-1.

Mainville, ibid at 105.

Ibid at $107-108$.

Ibid at 108. Note that Mainville's principles of compensation are endorsed in Brenda L Gunn, "More Than Money: Using International Law of Reparations to Determine Fair Compensation For Infringements of Aboriginal Title" (2013) 46:2 UBC L Rev 299. Gunn argues that compensation should include restitution, rehabilitation, satisfaction, and guarantees of non-repetition, endorsing a restorative approach with the goal of erasing the effects of the wrong while repairing and restoring damaged relationships. However, Gunn's article is not focused on calculating the quantum of economic accommodation and thus largely falls outside the scope of this article. 
C. compensation is to be determined in accordance with federal common law and will thus be governed by rules that apply uniformly throughout Canada;

D. compensation is generally the responsibility of the Crown but may, in appropriate circumstances, be assumed by third parties;

E. compensation may be provided through structured compensation schemes or through a global monetary award;

F. compensation is normally to be awarded for the benefit of the affected Aboriginal community as a whole. ${ }^{54}$

This approach offers an interesting perspective on how to value rights that do not easily fit into common law boxes due to their unique, communal, sui generis nature. However, Mainville's approach, in its grounding in fiduciary law and rejection of expropriation principles, diverges from the principles of compensation set out in other areas, such as modern treaties or legislation dealing with Aboriginal title or rights. ${ }^{55}$

\section{B. COMPENSATION FOR EXPROPRIATION}

Assessing the nature of an infringed interest and the severity of the infringement is similar in some respects to the tasks undertaken when compensation is available as a remedy. The area of expropriation law provides one example. While circumstances involving expropriation and Aboriginal title infringement have some similarities, expropriation principles cannot be solely used to determine compensation given the significant differences between fee simple and Aboriginal title and the need to approach Aboriginal title from the perspective of both the common law and the Aboriginal perspectives. ${ }^{56}$ That said, these principles are still relevant to consider, and it is notable that expropriation-type principles of compensation have found their way into modern Aboriginal contexts involving valuation assessments for impacts caused to traditional uses and ways of life. Certain examples of these contexts are detailed below, including modern treaties and statutory regimes governing compensation for Aboriginal rights, such as the Métis Settlements Act and the First Nations Land Management Act. ${ }^{57}$

55 See also the analysis of Mainville's principles of compensation in Bob Adkins \& Sacha R Paul, "Compensation or Damages as a Remedy for Breaches of Indigenous Rights" (Paper delivered at the Manitoba Bar Association, 2012), online: $<$ www.tdslaw.com/site-files/compensation_or_damages_as a remedy for breaches.pdf $>$. The authors consider the evolution in Aboriginal law since the Mainville text, notably the reduced focus on fiduciary duty as the basis of Crown obligation in favour of the broader concept of honour of the Crown endorsed by the Supreme Court in Haida, supra note 27. With respect to third party liability for impacts to Aboriginal title (an issue discussed in some detail by Mainville), the authors argue that the Haida decision "eliminates the possibility of basing a theory of third party liability on the fiduciary duty or the Honour of the Crown" and instead consider alternative bases for third party liability, including property law principles (ibid at 17).

56 Delgamuukw, supra note 1 at para 84. The Court in Delgamuukw explains that Aboriginal title "is also sui generis in the sense that its characteristics cannot be completely explained by reference either to the common law rules of real property or to the rules of property found in aboriginal legal systems. As with other aboriginal rights, it must be understood by reference to both common law and aboriginal perspectives" (ibid at para 112); Marshall, supra note 19 at paras 46-54.

57 Métis Settlements Act, RSA 2000, c M-14 [MSA]; First Nations Land Management Act, SC 1999, c 24 [FNLMA]. 
Expropriation is typically the result of government action affecting the rights enjoyed by its citizens. The compulsory taking of property is "one of the ultimate exercises of governmental authority [constituting] a severe loss and a very significant interference with a citizen's private property rights. ${ }^{, 58}$ The government action is for the purpose of advancing a public interest objective. The action results in an interference with the use and enjoyment of land rights, and compensation is intended to address those impacts.

Compensation principles for expropriation were the subject of fundamental reforms in the 1960 s, which led to the current, codified system found in legislation across Canada. Unclear and inconsistent interpretations of pre-reform compensation concepts such as "value to the owner" and "due compensation" involved the use of various legal fictions and did not prioritize the process to affected landowners. Two seminal processes and reports formed the basis for reform: (1) the 1968 Ontario Law Reform Commission study and report, Report on the Basis for Compensation on Expropriation; and (2) the Royal Commission to examine whether any of Ontario's laws included unjustified encroachments on Ontarians' civil rights (collectively, the Reports). ${ }^{59}$ These were, in effect, the means by which the Ontario public was consulted on how Crown interference with private land rights would take place.

The Reports recognized the seriousness of the interference to property rights caused by expropriation, emphasized the goal of indemnification, and that compensation should be calculated using clearly stated principles. As noted in Dell Holdings, the fundamental objectives stressed in the Reports were: (1) ensuring the state fulfills "its obligation to repair the injury caused to particular individuals for the public good, and to minimize the loss, inconvenience, and disturbance to the life of its citizens to as great an extent as possible",;0 and (2) codifying a compensation framework with "sufficient flexibility to allow for indemnification in various circumstances." These objectives then gave rise to compensation determinations that used market-based valuation techniques, and in special circumstances used equivalent reinstatement principles. $^{62}$

Under market-based principles, valuation of an expropriated interest or right occurs at the time of the taking, based on the highest and best use of the expropriated interest or right, and includes any decrease in value to the remaining property of the owner. ${ }^{63}$ Valuation is based on the market value of the property, being the amount that would have been paid for the interest if, at the time of its taking, it had been sold in the open market by a willing seller to

Toronto Area Transit Operating Authority v Dell Holdings Ltd, [1997] 1 SCR 32 at para 20 [Dell Holdings].

59 Ontario Law Reform Commission, Report of the Ontario Law Reform Commission on the Basis for Compensation on Expropriation (Toronto: Department of the Attorney General, 1967) at 9 [OLRC Report]; Royal Commission Inquiry into Civil Rights, Report No 1, Vol 3 (Toronto: Queen's Printer, 1968) [Royal Commission Report]: In Ontario, this included 60 separate statutory grants of expropriation powers, 26 different types of expropriation authorities, and over 8,000 individual organizations, from provincial highway departments and hydroelectric commissions, to cancer foundations and the Liquor Control Board of Ontario. Reform began in Ontario with the Interim Report of Select Committee on Land Expropriation (Toronto: Queen's Printer, 1961) and An Act respecting the Procedures for Expropriating Lands and Determining Compensation for the Expropriation or Injurious Affections of Lands, SO 1962-63, c 43, and procedurally, the Royal Commission Report criticized the proliferation of expropriating authorities, and recommended the formation of a single, expert tribunal with rights of appeal to the court of appeal. Dell Holdings, supra note 58 at paras 17 [emphasis omitted], citing OLRC Report, ibid at 11.

Dell Holdings, ibid at para 18.

Coates \& Waqué, supra note 50 at 33-1.

Expropriation Act, RSC 1985, c E-21, s 25 [Federal EA]. 
a willing buyer. ${ }^{64}$ These market assessments are typically based on professional appraisers' expert evidence, most commonly using the "comparative sales" appraisal technique. ${ }^{65}$

Equivalent reinstatement principles apply where the expropriated interest involves special uses, for instance schools, hospitals, and religious or charitable institutions. Compensation will be based upon the value required to reinstate the landowner with an equivalent property for the special use where: (1) the expropriation causes the underlying purpose to be rendered impracticable to the owner; (2) the purpose would have continued but for the expropriation; and (3) there was no general demand or market for that interest or right for that purpose. ${ }^{66}$ In these cases, a "higher of" calculation is used. This calculation compares the market value of the expropriated interest and the aggregated costs of reasonable alternative interests in land, plus the costs, expenses, and losses arising out of, or incidental to, moving and reestablishing the purpose. If such costs cannot be practically estimated, legislation may prescribe a maximum percentage amount of the market value for the land interest, less deductions for potential improvements in position due to re-establishment. ${ }^{67}$

Other compensation principles codified in present day expropriation legislation (which effectively resulted from the Reports) include specific heads of disturbance damages. ${ }^{68}$ These include relocation and inconvenience costs, business losses, and legal and appraisal costs. Depending on the jurisdictions involved, compensation may also be provided for "injurious affection" that may be caused to remainder land interests. ${ }^{69}$ Compensation will be awarded for injurious affection where a partial taking is involved (or in some jurisdictions where no taking is involved), and the taking results in the owner sustaining adverse economic impacts to the use and value of the aggrieved owner's remaining land interests. ${ }^{70}$

In circumstances where no property interest is actually taken from the aggrieved landowner, but damage nevertheless accrues to property from an action taken under statutory authority, claimants must prove three statutory requirements: (1) "the damage must result from action taken under statutory authority"; ${ }^{\prime 1}(2)$ but for the statutory authority, the action would give rise to liability $;^{72}$ and (3) the damage must result from the construction and not

Eric CE Todd, The Law of Expropriation and Compensation in Canada, 2nd ed (Toronto: Carswell, $1992)$ at $131-34$.

65 Todd, ibid (comparative sales, also called the "market data" approach, is a method of appraisal that "compares the subject property with market data, including the sales prices of comparable properties" at 181). See also Coates \& Waqué, supra note 50 at 33-47.

66 Todd, ibid (where the property has no ascertainable market value in the commercial sense, the principle of equivalent reinstatement has been judicially defined as "placing the owner from whom the property is taken in a substantially equivalent condition by means of substituted property" at 228, citing $R V$ Northumberland Ferries Ltd, [1945] SCR 458).

$67 \quad$ Federal EA, supra note 63, s 26(5).

68 Ibid, s 26(3)(b)(ii); Expropriation Act, RSA 2000, c E-13, ss 42, 43, 50-52.

69 Antrim Truck Centre Ltd v Ontario (Transportation), 2013 SCC 13, [2013] 1 SCR 594 at para 4 [Antrim]:

Injurious affection occurs when the defendant's activities interfere with the claimant's use or enjoyment of land. Such interference may occur where a portion of an owner's land is expropriated with negative effects on the value of the remaining property. Alternatively, it may arise where, although no land is expropriated, the lawful activities of a statutory authority on one piece of land interfere with the use or enjoyment of another property. often calculated based on a percentage amount of the market value of the remaining property.

71 Antrim, supra note 69 at para 5. Ibid. 
the use of the works. ${ }^{73}$ When evaluating the second requirement, consideration is often given to the tort of nuisance as the underlying action. In Antrim, the Supreme Court of Canada held that for nuisance claims, in the context of a claim for injurious affection, a reasonableness analysis must be used to determine whether the impacts sustained by the private landowner are disproportionate to the costs of procuring the public benefit. Compensation is only afforded where: (1) the interference is substantial and not trivial; and (2) after considering all of the circumstances, it would be unreasonable to expect the claimant to bear the interference without compensation.

\section{EXPROPRIATION UNDER MODERN TREATIES}

As stated in Delgamuukw, any principles developed to provide appropriate compensation for impacts to Aboriginal title must incorporate the Aboriginal perspective. ${ }^{74}$ This is a difficult task since the interest is itself sui generis and the Aboriginal perspective varies depending on the land and group at issue. In each instance, there would need to be significant dialogue between the parties to understand the importance and use of the land, including its historic, current, and future intended use, among other things.

While these discussions are highly contextual, we believe that the compensation frameworks that have been included in modern land claim agreements provide some insight into how the Aboriginal perspective could be assessed and valued. These agreements were the subject of years of negotiation between the Crown and Aboriginal groups that specifically turned their minds to this difficult issue. Many underscore the desire for compensation to take the form of suitable alternative lands or equivalent reinstatement.

In the Inuvialuit Final Agreement, for example, monetary compensation for expropriation is secondary to the primary obligation of Canada to provide "suitable alternative lands in the Western Arctic Region, considered to be satisfactory by the Inuvialuit, in place of the [expropriated] lands if it is reasonably possible to so provide." 75 If replacement lands cannot be provided, monetary compensation is payable "as contemplated by the Expropriation Act of Canada." 76 The exception to this principle is that a "higher of" calculation, as between fair market value of the land and an undefined "cost base," which may otherwise be agreed to by the parties. ${ }^{77}$

Similar provisions concerning market value and equivalent reinstatement are seen in the Nisga'a Final Agreement. ${ }^{78}$ Canada's obligations with respect to compensation in the

Ibid.

Delgamuukw, supra note 1 at para 81.

Inuvialuit Final Agreement, 18 August 1979, s 7(51) (entered into force 25 July 1984).

Ibid, s 7.(52).

Ibid, s 7.(53): The monetary compensation payable on an expropriation shall reflect the fair market value of the lands expropriated but shall take into account that such value is low relative to other areas in Canada and that this Agreement is intended to constitute a fair exchange between the Inuvialuit and Canada. Where a cost base is agreed upon, the compensation payable on an expropriation shall be an amount equal to the greater of the fair market value and that cost base.

78 Nisga'a Final Agreement, 27 April 1999, ch 3 at para 81 (entered into force 11 May 2000): If there is an expropriation under paragraph 74 of the estate in fee simple as described in paragraph 3 in a parcel of Nisga'a Lands, or of the estate in fee simple in a parcel of Nisga'a Fee Simple Lands, Canada will, at the request of Nisga'a Lisims Government, ensure that 
Nisga'a Final Agreement include, among others: (1) the cost of equivalent reinstatement; (2) the market value of the estate or interest expropriated; (3) the replacement value of any improvements on the land that is expropriated; (4) any disturbance caused by the expropriation; and (5) adverse effects on any cultural or other special value of the land. ${ }^{79}$

Under the Labrador Inuit Land Claims Agreement, the principles of market value and equivalent reinstatement are found, but are directed towards achieving certain objectives. Section 4.18.5 of the Labrador Inuit Land Claims Agreement provides a Crown Expropriation Authority with the discretion to offer compensation in the form of other lands of "equivalent significance and value." ${ }^{80}$ However, the Nunatsiavut Government (or a person claiming under the Nunatsivut Government) is not required to accept compensation in the form of other land. Moreover, if at any time 12 percent of the Labrador Inuit Lands have been and remain expropriated, no further expropriations are permitted "unless the Expropriation Authority provides compensation that includes an amount of previously Expropriated Labrador Inuit Lands equivalent in significance and value to the Labrador Inuit Lands proposed for Expropriation." ${ }^{\text {"1 }}$ Equivalent reinstatement is thus an overarching principle.

Market valuation principles for the expropriated Labrador Inuit Lands are found in a list of compensation factors which an arbitration panel must consider. Compensation provisions strongly suggest that compensation for injurious affection-type harms is contemplated, as compensation is provided for: (1) loss of use; (2) adverse effects on other lands, damage to the unexpropriated interest, and nuisance (meaning injurious affection-type claims, as discussed); (3) any cultural attachment of the Inuit to the expropriated land; (4) effects on wildlife, harvesting, and habitats; (5) any particular or special value of the expropriated land to the Inuit; (6) reasonable costs of negotiation, mediation, or arbitration; (7) market value of the expropriated land; and (8) whether other land is offered in compensation and, if so, the significance and value of that land. ${ }^{82}$

Further, some modern land claim agreements also deal with compensation for other damages associated with expropriation beyond the expropriated interest. As noted above, the Labrador Inuit Land Claims Agreement includes what may be categorized as a third grouping of damages, by considering impacts to the cultural attachment of Inuit to the expropriated land, effects on wildlife habitat and harvesting, and any particular or special value to Inuit of the expropriated lands. ${ }^{83}$

reasonable efforts are made to acquire alternative land of equivalent significance and value to offer as part or all of the compensation for the expropriation. Any alternative land that is contiguous with Nisga'a Lands may become Nisga'a Lands in accordance with paragraph 9.

Ibid.

Land Claims Agreement Between the Inuit of Labrador, Her Majesty the Queen in Right of Newfoundland and Labrador and Her Majesty the Queen in Right of Canada, 22 January 2005, s 4.18.5 (entered into force 1 December 2005) [Labrador Inuit Land Claims Agreement].

Ibid, s 4.18.10.

Ibid, s 4.18.7.

Compensation for adverse effects to cultural or other special values related to an expropriation is seen in other treaties. See e.g. Nisga'a Final Agreement, supra note 78, ch 3 at para 82. Compensation for cultural-based losses is not expressly stated in the Inuvialuit Final Agreement, supra note 75; however, compensation for the "intrinsic value for wildlife" is stated (ibid, s 7.(54), 7.(60)(c)). Arguably, this is not a meaningful distinction, given the underlying purposes and objectives of indemnification in the context of Aboriginal peoples. 
Valuation challenges arise with the third grouping of damages. Methods or principles to quantify diminishment of cultural attachment to lands are undefined in these aforementioned treaties. This issue has received limited judicial consideration. In Nunavut Tunngavik Inc. v. Canada (Attorney General), alleged breaches to treaty rights resulting in loss of enjoyment of culture or damage to a traditional lifestyle, was described by Justice Kilpatrick as harm that "may not be curable, or quantifiable in practical terms." 84

However, the valuation of cultural impacts has arisen in a legislative context, such as in Alberta's MSA or the FNLMA regime, as discussed below.

\section{MÉtis SETTLEMENTS ACT}

Alberta's MSA provides another useful example of expropriation-type compensation principles being applied to the valuation of Aboriginal rights. The MSA was enacted as part of a package of legislation and financial agreements which resulted from the signing of the Métis Settlements Accord on 1 July 1989, and amendments to Alberta's Constitution. ${ }^{85}$ The MSA is part of a modern statutory basis for the protection of Metis rights and Metis Settlements, and includes a partial self-government regime: "[ $\mathrm{t}]$ he purpose and effect of the MSA is to enhance Métis identity, culture, and self-governance by creating a land base for [the] Métis" in Alberta. ${ }^{86}$

The MSA addresses, among other things, the manner in which surface access may be provided to existing mineral lease holders and certain prescribed operators for the purposes of carrying out various types of projects, including oil and gas, electric generation, and mining projects. ${ }^{87}$ When compensation disputes arise for requested access, an independent tribunal must consider any relevant development agreement, and may consider any of the principles stated in section 118(1) of the MSA:

In determining the amount of money payable by an existing mineral lease holder or operator to an occupant as compensation, the Existing Leases Land Access Panel or the Land Access Panel must consider any relevant development agreement and may consider the following:

(a) the value of the parcel of land affected, including

(i) the cultural value for preserving a traditional Metis way of life,

(ii) the economic value as an asset, and

(iii) the productive value;

(b) damage in the specific existing mineral lease or authorized project area, including

Nunavut Tunngavik Inc v Canada (Attorney General), 2003 NUCJ 1, [2004] 1 CNLR 197 at para 43. MSA, supra note 57; Constitution of Alberta Amendment Act, 1990, RSA 2000, c C-24; Alberta (Aboriginal Affairs and Northern Development) v Cunningham, 2011 SCC 37, [2011] 2 SCR 670 at paras 8-18 [Cunningham].

Cunningham, ibid at para 3.

MSA, supra note 57. 
(i) the effect of the lease or project on the present and planned use of the parcel and surrounding area,

(ii) the special damages to improvements, crops, wildlife, livestock, trap lines and natural vegetation resulting from the lease or project, and

(iii) the amount of the lease or project area that the existing mineral lease holder or operator may damage;

(c) the impact of the lease or project on other areas, including

(i) disturbance to the physical, social and cultural environment,

(ii) location of the lease or project in relation to existing or planned community uses, and

(iii) other specific matters, such as the cumulative effect of related projects;

(d) any agreement, in addition to a development agreement, entered into by an existing mineral lease holder or operator and the General Council or an occupant;

(e) any other factors the Panel considers appropriate. ${ }^{88}$

In many respects, this section is similar to provisions commonly seen in expropriation legislation. For instance, independent tribunals are used in expropriation proceedings to make compensation determinations for takings of private land. Section 118(1) lists a number of principles for the purpose of assessing compensation which mirror traditional, market-based valuation methods found in expropriation legislation, such as the productive value of the land, economic value of the land as an asset, or special damages to improvements. However, the MSA specifies other considerations in addition to market-based metrics, which reflect the purposes of the legislation. Valuation determinations may take into account cultural impacts caused to the affected land that impact traditional Metis ways of life, namely: (1) the "cultural value [of the parcel of land] for preserving a traditional Metis way of life"; 89 (2) "disturbance to the physical, social and cultural environment" other areas; and (3) "other specific matters, such as the cumulative effect of related projects." 91

To date, there has been limited judicial consideration of the non-traditional market-based valuation principles set out in section 118(1) of the MSA. Two recent cases heard by the Métis Settlements Appeal Tribunal (Land Access Panel) (the Panel) considered a "structured decision-making" methodology (SDM Approach), which was proposed to address nontraditional market attributes such as environmental and cultural loss resulting from historical and ongoing industry access. ${ }^{92}$

Ibid, s 118(1).

Ibid, s $118(1)(\mathrm{a})(\mathrm{i})$.

Ibid, s $118(1)(\mathrm{c})(\mathrm{i})$.

Ibid, s $118(1)$ (c)(iii).

Robin Gregory \& William Trousdale, "Compensating Aboriginal Cultural Losses: An Alternative Approach to Assessing Environmental Damages” (2009) 90:8 J Environmental Management 2469. 
Under the SDM Approach, compensation for environmental and cultural loss takes into account multiple subjective dimensions of valuation, as it relates directly to the impacted party. ${ }^{93}$ In pursuit of this objective, the SDM Approach examines cultural impacts and cumulative effects of development through a community consultative process. Through consultative efforts, careful steps are taken to derive value attributes or identify dimensions of impact, which are then measured using a variety of techniques, including, natural measures (for example, acres of lost wildlife habitat), use of proxy estimates (for example, diseased trees per hectare as a proxy for the health of a forest community or levels of air emission impacts), or the use of constructed metrics. ${ }^{94}$

The Panel rejected the SDM Approach due to the level of subjectivity involved, as well as the lack of objective and independent verification of the identified community perceptions and monetary allocators used to approximate value. ${ }^{95}$ Further, the Panel expressed concern over the nature of the impacts complained of, namely, whether impacts to traditional cultural activities such as loss of language, change in diet, or health issues could objectively be demonstrated as arising from the impugned oil and gas operations, rather than general societal changes. ${ }^{96} \mathrm{~A}$ final area of criticism was the overall appropriateness of the methodology for assessing rights-based compensation disputes, versus its use in environmental planning purposes. ${ }^{97}$

Given the Panel's well-founded concerns, it is unlikely that the SDM Approach can be used in a cultural impact compensation assessment exercise without significant overhaul. That said, the lessons learned from this exercise may perhaps be summarized as follows:

Ibid at 2476.

Ibid: An example of a constructed metric is the development of a scale to measure community concerns or support for particular industrial activities, such as surface impacts from oil and gas activities. Through interaction with community members, attributes affecting the loss are identified (for example, alteration to land from cutlines or well sites, alteration of landscape from wells and pipelines, or alteration of landscape from temporary purposes like access). These attributes are then ranked (in terms of intensity and perceived impact) and weighted in terms of their overall contribution to the cultural losses experienced by the community. These conclusions are then ultimately assigned what appears to be some arbitrary monetary valuation amounts, based on overall revenues received by the community and an allocation or distribution of relative impacts of the impugned activity to the overall amount. Gift Lake Métis Settlement v Devon Canada Corporation (12 April 2007), MSAT Order No 176 at 64, online: MSAT < www.msat.gov.ab.ca/appeals/pdf/Order_No.176.pdf> [MSATOrder]. Leave to Appeal to the Court of Appeal on the Land Access Panel's assessment of evidence and preference of Devon Canada Corporation's expert evidence was denied: Gift Lake Métis Settlement v Métis Settlements Appeal Tribunal (Land Access Panel), 2008 ABCA 43, 2008 ABCA 43 (CanLII). In the more recent Land Access Panel decision, Kikino Metis Settlement v Husky Oil Operators Ltd (2 December 2015), MSAT Order No 273 at para 170, online: MSAT <www.msat.gov.ab.ca/appeals./pdf/Order No. 273.pdf $>$, the subjectivity concern was stated as follows:

It is difficult to know the impact, if any, of self-serving bias effects in this [SDM] approach but we think they exist. Members being consulted by an outside firm about their values would have been informed, and would have known, what this exercise was designed to calculate. Most rational, self-interested individuals would seek to establish a value ordering that would generate the most favourable compensation from Husky.

96 MSAT Order, ibid at 43.

97 Ibid at 64. The Panel's approach regarding the methodology for the valuing of cumulative effects under section 118(1)(c) of the MSA, supra note 57, was heard by the Alberta Court of Appeal in Gift Lake Métis Settlement v Métis Settlements Appeal Tribunal (Land Access Panel), 2009 ABCA 143, 454 AR 53. This decision has important evidentiary ramifications in the context of surface lease renewals. The compensation for cumulative effects is narrowed. The onus is on the claimant to demonstrate that the specific effects complained of are due to the specific development, are ongoing, and are expected to continue during the renewal period. Compensation for the impacts in prior periods is not provided. The standard of review on these issues is reasonableness, thus affording deference to the trier of fact. 
- the field remains open for the introduction of new valuation methods used to assess diminishment in cultural impacts;

- any approach must start by gaining an understanding of the impugned cultural features by consulting with the Aboriginal community;

- $\quad$ steps must be taken to independently verify subjective perceptions of loss;

- objective methods must be used to quantify the independently verified impacts, and then it must be proved that such impacts must directly result from the impugned activity or proponent; and

- $\quad$ payments made by others in the immediate area may be relevant considerations for renewals of access rights, historical compensation payment amounts, and changes that have occurred since the expiration of those payments but the onus is on the party alleging same to demonstrate that analogous circumstances arise.

\section{E. FirSt NATIONS LAND MANAGEMENT ACT}

The legislative regime established by the FNLMA allows approved First Nations to opt out of a number of sections of the federal Indian Act relating to land management for the purpose of providing a scheme wherein those First Nations can develop their own laws respecting land use, and environmental and natural resources matters. ${ }^{98}$

Under section 29 of the FNLMA, the Crown may expropriate First Nation land ${ }^{99}$ with the consent of the Governor in Council, which may only be given if the expropriation is "justifiable and necessary for a federal public purpose that serves the national interest."100 Section 29(3) provides four requirements that must be met in order for the Governor in Council to provide such consent:

(a) there is no other reasonably feasible alternative to the expropriation, such as the use of land that is not First Nation land;

(b) reasonable efforts have been made to acquire the interest or right through agreement with the First Nation;

(c) the most limited interest or right necessary is expropriated for the shortest time possible; and

(d) information relevant to the expropriation is provided to the First Nation. ${ }^{101}$

The Framework Agreement on First Nation Land Management was signed by the Government of Canada and 14 First Nations and subsequently ratified by the FNLMA, supra note 57, in 1999, establishing the First Nations Land Management Regime. As of January 2016, 95 First Nations have entered the FNLM regime: Indigenous and Northern Affairs Canada, "First Nations Land Management Regime" (Ottawa: Indigenous and Northern Affairs Canada, 22 September 2016), online: < https://www. aadnc-aandc.gc.ca/eng/1327090675492/1327090738973>. rights in, and resources of, the land that are within the legislative authority of Parliament" (ibid at s 2(1)). 
If these requirements are met and the land is expropriated by the Crown accordingly, the FNLMA requires that compensation be provided to the First Nation consisting of land that will become First Nation land (when accepted by the First Nation), as well as "any additional compensation required to achieve the total compensation determined under subsection (3)." "102 Subsection (3) of section 31 lists the factors that should be considered when determining the "total compensation" awarded:

(a) the market value of the expropriated interest or right or of the land in which an interest or right has been expropriated;

(b) the replacement value of any improvement to the land;

(c) any expenses or losses resulting from a disturbance attributable to the expropriation;

(d) any reduction in the value of any interest or right in First Nation land that is not expropriated;

(e) any adverse effect on any cultural or other special value of the land to the First Nation; and

(f) the value of any special economic advantage arising out of or incidental to the occupation or use of the land to the extent that that value is not otherwise compensated. ${ }^{103}$

The First Nations Land Management regime thus provides a similar set of expropriationlike principles as section 118(1) of the MSA, including consideration of market value and disturbance damages. In particular, section 31(3) of the FNLMA requires consideration of any adverse effect on cultural or special value of the land to the First Nation. As discussed above, this consideration poses a number of difficulties and requires creative solutions to valuing such impacts.

\section{Australian Experience}

Canada is not the only country that has had to grapple with issues relating to Aboriginal title. Australia is an interesting comparator, given that both countries have significant Aboriginal populations and share a number of legal and constitutional characteristics, including similarities in their respective colonial histories as commonwealth countries. ${ }^{104}$

On the issue of Aboriginal title, ${ }^{105}$ the highest courts in both countries have proclaimed Aboriginal title as a unique, sui generis property interest, and have rejected the doctrine of

Ibid, s 31(3)(a)-(f). To the authors' knowledge, there has been no judicial consideration of this section of the FNLMA; the FNLMA does, however, provide an arbitration process where agreement on compensation cannot be reached between the First Nation and the Crown: ibid, s 31(5).

104

Katja Göcke, "Protection and Realization of Indigenous Peoples' Land Rights at the National and International Level” (2013) 5:1 Goettingen J Intl L 87 at 92, citing $R v$ Steel, [1834] NSW Legge SC 1, [1834] 1 Legge 65 at 68-69: "[t]he right to the soil, and of all lands in the Colony, became vested immediately upon its settlement, in His Majesty, in the right of his crown, and as representative of the British Nation."

105 For the sake of consistency this article refers to Australian "native title" as "Aboriginal title." See explanation in note 7 , above. 
terra nullius. ${ }^{106}$ Further, Aboriginal title in Australia is also a "burden" or "qualification" on the Crown's radical title, crystallizing upon acquisition of sovereignty. ${ }^{107}$ There are, however, some significant differences between the legal frameworks on this issue, the most important of which is the lack of constitutional protection of Aboriginal title in Australia. ${ }^{108}$ Additionally, the Australian Crown has never been declared to owe a fiduciary duty to Aboriginal peoples and the Australian courts have not recognized a broad duty to consult for impacts to asserted but not yet proven Aboriginal rights. However, there is a right to negotiate for impacts of certain Crown activities on Aboriginal title claims that meet a number of prescribed requirements.

The Australian approach to resolving Aboriginal title claims has proceeded in a very different direction than in Canada. Specifically, Australia has introduced a comprehensive, mandatory statutory regime, the Native Title Act, to determine assertions of Aboriginal title and compensation related thereto, including for future acts such as resource development projects. ${ }^{109}$ From 1 January 1994 to 1 April 2015, there have been 2,114 Aboriginal title applications, more than half of which have been discontinued, dismissed, or struck out, ${ }^{110}$ a significant portion of these were discontinued, dismissed, or struck out at a preliminary stage. As of 1 April 2015, there had been 308 Aboriginal title determinations, 248 of which found that Aboriginal title existed in at least part of the determination area. Interestingly, 234 of these determinations were ultimately on consent after mediation. ${ }^{111}$ This is quite a significant contrast to Canada, which has had only one declaration of Aboriginal title and no declarations of Aboriginal title on consent.

The NTA also provides for "just compensation" in certain circumstances, including for future acts. However, similar to Canada, Australia has struggled to develop consistent principles to determine such compensation.

\section{A. The Native Title ACt}

The NTA provides processes and principles for determining Aboriginal title claims, and compensating for impacts to Aboriginal title. ${ }^{12}$ In passing the NTA, the goal of the Australian Parliament was to strike a balance between two competing goals: (1) recognition and protection of Aboriginal title; and (2) certainty of property rights for other members of the Australian population who may be affected by Aboriginal title determinations. ${ }^{113}$

Mabo v Queensland (No 2), [1992] HCA 23, 175 CLR 1 [Mabo 2]. Notably, the High Court of Australia cited Guerin, supra note 48, in setting out this principle: Australian common law recognizes a form of Aboriginal title which "reflects the entitlement of the indigenous inhabitants, in accordance with their laws or customs, to their traditional lands" (Mabo 2, ibid at 15); Delgamuukw, supra note 1 at para 112. Mabo 2, ibid at 7. See also Melissa Perry \& Stephen Lloyd, Australian Native Title Law (Montreal: Carswell, 2003) at 11-12.

Mabo 2, ibid; although there was some indication in Australian jurisprudence that Aboriginal title may fall within the ambit of the Australian Constitution, this proposition has never been confirmed in case law. Native Title Act 1993 (Cth), s 13A [NTA] (as amended in 1998, 2007 \& 2009).

The total number of claims that have been discontinued, dismissed, or struck out is 1,155 claims. Australia, Commonwealth Law Reform Commission, Connection to the Country: Review of the Native Title Act 1993 (Cth) (Report No 126) (Sydney: Australian Law Reform Commission, 2015) at 93-94 [Connection to the Country].

112 See e.g. Dwight G Newman, The Duty to Consult: New Relationships with Aboriginal Peoples (Saskatoon: Purich, 2009) at 87-92.

113 Connection to the Country, supra note 111 at 12. 
As a result of further amendments to the NTA in 1998, the Federal Court of Australia is responsible for managing all aspects of Aboriginal title cases. Pursuant to the NTA, the Federal Court of Australia may, among other things: (1) make determinations respecting the establishment of, and compensation for, Aboriginal title; ${ }^{114}$ (2) refer Aboriginal title and compensation applications for mediation; ${ }^{115}$ and (3) make orders giving effect to the terms of agreements reached by parties to proceedings, including terms involving matters other than Aboriginal title. ${ }^{116}$ Further, the NTA establishes the National Native Title Tribunal, which is empowered to: (1) make determinations concerning whether certain future acts may be done on lands subject to registered Aboriginal title claims or established Aboriginal title, and whether certain agreements are to be covered by the NTA; and (2) provide assistance or undertaking mediation in other matters concerning Aboriginal title. ${ }^{17}$

The NTA prescribes specific information that must be included in an application for Aboriginal title. Once a claim is accepted by the Federal Court for filing, it is sent to the Registrar of the National Native Title Tribunal to determine whether the claim meets several conditions set out in the NTA and can be registered. Registration affords the affected group certain procedural rights while their claim is being determined, including a right to negotiate vis-à-vis future acts while their claim is being determined. ${ }^{118}$ The National Native Title Tribunal will ultimately determine whether such future acts can proceed and the conditions to be attached if an agreement is not reached between the parties within a prescribed period. Once a group has established that Aboriginal title exists, the NTA entitles the group to compensation for the extinguishment or infringement of title. ${ }^{119}$ Two discrete compensation regimes are contemplated under the NTA: agreement-based and court-based. ${ }^{120}$ Each regime struggles with the basic question of how to determine the proper quantum or other types of compensation. ${ }^{121}$ The agreement-based regime, discussed in greater detail below, involves the negotiation of Indigenous Land Use Agreements (ILUAs), in which parties arrive at mutually acceptable terms of compensation via independent and private negotiations. The court-based regime provides for the determination of compensation where agreements cannot

NTA, supra note 109, s 4(7)(a).

Ibid, s 4(7)(aa).

Ibid, s 4(7)(ab).

Perry \& Lloyd, supra note 107 at 6.

Although outside the scope of this article, the concept of establishing a system for registering claims that meet certain specified criteria which then gives rise to a right to negotiate on future impacts may provide a potential model for addressing the uncertainties associated with negotiating compensation for impacts to asserted Aboriginal title rights in the Canadian context.

Note that Australian jurisprudence supports the principle that extinguishment of Aboriginal title cannot occur without compensation unless there is clear and plain legislative authority for such a result: Wik Peoples $v$ Queensland, [1996] HCA 40, 187 CLR 1; Amodu Tijani v Southern Nigeria (Secretary), [1921] 2 AC 399 (PC); Richard H Bartlett, Native Title in Australia, 2nd ed (Sydney: Butterworths, 2004) at 547; NTA, supra note 109, ss 17-20 (past acts), 22D, 22E, 232A ("intermediate period act" is any act which took place between 1 January 1994, and 23 December 1996, subject to certain specific exceptions), s 24FA (future acts), and s 23J (previous exclusive or non-exclusive possession acts). See also Robyn Glindemann \& David Bursey, "Compensation and Native Title Rights in Australia and Aboriginal Rights in Canada: An Overview" (2001) 20:3 Austl Mining \& Petroleum LJ 288 at 289. John Litchfield, "Compensation for Loss or Impairment of Native Title Rights and Interests: An Analysis of Suggested Approaches (Part I)" (1999) 18:3 Austl Mining \& Petroleum LJ 253 at 253. Parties may apply to the Australian Federal Court of Appeal for determinations of the applicable compensation: NTA, supra note 109, ss 50(1), 50(2).

Note that the NTA requires that the outcome of compensation be payment of money, unless the court, body, or person making the determination of compensation agrees to some other form: NTA, ibid, ss 51(5), 51(6). 
be reached. There are two measures used for its calculation: (1) compensation based on the "similar compensable interest test"; and (2) compensation on "just terms."

Compensation based on a "similar compensable interest" essentially means that the compensation payable is what would have been payable had the Aboriginal title holders instead held fee simple title to the area in question. ${ }^{123}$ Where no similar comparable interest exists, an entitlement on "just terms" is required to compensate the Aboriginal title holders "for any loss, diminution, impairment or other effect of the act" on Aboriginal title. ${ }^{124}$ "Just terms" is aimed at placing the holder in a similar position as if their rights had not been extinguished. Interestingly, the concept of "just terms" in the NTA echoes the Australian constitutional protection against expropriation of private property without compensation. ${ }^{125}$

Unfortunately, determining the quantum of compensation on "just terms" has not received extensive judicial consideration in the Aboriginal title context, where market value is either not readily ascertainable, or is an insufficient measure of the value of the land at issue to Aboriginal persons. ${ }^{126}$ Based on available jurisprudence and scholarship, the best estimate of a formula is that "just terms" encompasses a notion of market value, plus the noneconomic value placed on the land by Aboriginal persons. Australian jurisprudence has unfortunately thus far failed to provide benchmarks or principles for calculating compensation going forward. ${ }^{127}$

NTA, ibid, s 51. See also Litchfield, supra note 120 at 254.

The NTA provides for circumstances in which compensation is payable under another statute (such as the Mineral Resources Act 1989 (Qld) or Petroleum and Gas (Production and Safety) Act 2004 (Qld), which require compensation to landowners for activities affecting their enjoyment of their property). This is called the "similar compensable interest test" and assumes that the Aboriginal title holders held ordinary title to the land (NTA, ibid, s 240). "Ordinary title" is a freehold estate in fee simple, or in the Australian Capital Territory or the Jervis Bay Territory a lease granted by the Commonwealth, other than an estate or lease for the benefit of Aboriginal peoples of Torres Strait Islanders (NTA, ibid, s 253).

NTA, ibid, s 51(1). Compensation is limited by reference to freehold estate value; however, section 51A takes effect subject to section 53, which is a broader "safety net" provision describing the "just terms" standard (ibid, s 51A): Bartlett, supra note 119 at 584-85.

Commonwealth of Australia Constitution Act 1900, ss 63-64; Bank of New South Wales v Commonwealth (1948), 76 CLR 1 at 349-50. Although it has not been found that extinguishing Aboriginal title falls within the ambit of this constitutional protection, the compensation principles in the NTA nonetheless were likely formed with a view to the Commonwealth Constitution. See Bartlett, supra note 119 at 549 .

The first determination of Aboriginal title under the NTA was in Dunghutti People v New South Wales and Ors, [1997] FCA 1624 [Dunghutti], in which the Dunghutti people and the New South Wales Government had reached agreement with respect to an area of land in Northern New South Wales over which title was to be extinguished. The agreement provided that "just terms" compensation would be provided to the Dunghutti title holders, up to 150 percent of the agreed market value of the subject land. See also Australia Parliamentary Joint Committee on Native Title, "The Native Title Amendment Bill 1997 - Tenth Report" (1997), s 6.5, online: <www.aph.gov.au/Parliamentary_Business/Committees/ Joint/Former_Committees/ntlf/completed_inquiries/1996-99/report_10/report/contents $>$ [Tenth Report]. Note that this decision was decided prior to the introduction of $N \bar{T} A$, supra note $109, \mathrm{~s} 51 \mathrm{~A}$.

The first order of compensation for the extinguishment or impairment of Aboriginal title under the NTA was in De Rose v State of South Australia, [2013] FCA 988 [De Rose], in which Australia's Federal Court of Appeal considered whether a negotiated settlement for compensation was on "just terms." Unfortunately, since the Australian Federal Court of Appeal's decision simply endorsed the settlement agreement rather than ordering compensation, its decision provides no analysis of how to calculate compensation for Aboriginal title. Also see e.g. Wanjie Song, "What's Next for Native Title Compensation: the De Rose Decision and the Assessment of Native Title Rights and Interests" (2014) 8 Indigenous L Bull 11 at 12. Searches of Dunghutti, ibid and De Rose, ibid, have provided no further cases citing these decisions. 


\section{B. Suggested Valuation Methods}

Despite the relative lack of judicial consideration of this issue, Australian scholarship surrounding the NTA has proposed various mechanisms designed to place a value on "just terms." However, the key difficulty of how to calculate a non-economic loss remains. ${ }^{128}$ Calculating non-economic value is crucial to calculating compensation on "just terms" for a number of reasons, not the least of which is that many areas over which Aboriginal title is claimed are also those with the least economic value. ${ }^{129}$

It has been argued that compensation for impacts to Aboriginal title ought to be assessed with reference to the value of the loss to an Aboriginal title holder, rather than to the commercial value of the relevant property. ${ }^{130}$ This concept is analogous to the "value to the owner" concept espoused in older Canadian expropriation law. The concept is typically used where the property contains a unique feature which provides a financial advantage to the owner, and has been described as what the owner would, "as a prudent man, at that moment, pay for the property rather than be ejected from it." 131 The difficulty with employing this concept is that a subjective inquiry provides little in the way of a clear, principled basis for calculation beyond assessment on a case-by-case basis.

\section{INDIGENOUS LAND USE AND IMPACT BENEFIT AGREEMENTS}

In practice, project development by way of negotiated private agreements in Australia has proceeded upon a parallel track to that in Canada. In Australia, such agreements are available as a workaround to the legislated "future acts" process in the $N T A,{ }^{132}$ and can be a useful vehicle for accommodating intended impacts to Aboriginal title. A "future act" will be valid if an ILUA has been agreed to between the parties, and the certain prescribed details of the agreement have been registered under the NTA. ${ }^{133}$

Registered ILUAs are binding on all Aboriginal title holders in the geographical area to which the agreement applies. ${ }^{134}$ However, the NTA has been criticized as eroding Aboriginal title holders' negotiating position by limiting procedural obligations to negotiate in areas

Principles suggested in Canadian scholarship for calculating non-economic loss include the damage principles used in personal injury law; see Adkins \& Paul, supra note 55 at 22: "the common law is no stranger to valuing things that lack a market value."

Paul Burke, "How Can Judges Calculate Native Title Compensation?" (2002) Australian Institute for Aboriginal and Torres Strait Islander Studies, Discussion Paper at 3 (in valuing pastoral leases in Central Australia, the typical valuation of the land itself is nearly zero, as the value is primarily comprised of livestock and any improvements upon the land). Tenth Report, supra note 126.

131 Diggon-Hibben Ltd $v$ R, [1949] SCR 712 at 715, cited in OLRC Report, supra note 59 at 14-15. From the buyer's perspective, the concept has been described as "that which a prudent man in their position would have been willing to give for the land sooner than fail to obtain it": Pastoral Finance Association Ltd v The Minister, [1914] AC 1083 (PC) at 1088, cited in the OLRC Report, supra note 59 at 13.

NTA, supra note $109, \mathrm{~s} 24 \mathrm{AB}(1)$ provides that to the extent a future act is covered by an Indigenous Land Use Agreement, sections 24AA(4)(a) to (k) of the NTA dealing with future acts do not apply, and section 24EB provides specific principles (such as non-extinguishment of title absent explicit inclusion in the agreement) governing such agreements. See also Glindemann \& Bursey, supra note 119 at 289; Newman, supra note 112 at 90 ; Litchfield, supra note 120 at 255. 
such as the renewal of mining leases, the development of private mining infrastructure, and mineral exploration. ${ }^{135}$

Similar to Canada, negotiated agreements are only subject to the limitations of the parties' imaginations when it comes to potential terms. Compensation may include, and has included in some cases:

- cash payments at the outset of the project, periodically, at the achievement of project milestones, or some combination of all of the foregoing;

- a share in royalty or profit streams from the development of the resource or project, which can take the form of flat-rate royalties or more complex arrangements; ${ }^{136}$

- partial ownership of the project or other joint venture arrangements;

- other business opportunities such as preferred access to project-related contracts for Aboriginal businesses; ${ }^{137}$

- $\quad$ special education and training initiatives, including on the job training or scholarship and bursary programs;

- employment opportunities preferential to Aboriginal groups;

- community involvement and support for community programs;

- $\quad$ purchase of additional land or replacement of land in exchange for impacted territory; and

- $\quad$ specific environmental compliance requirements, or special conditions designed to protect culturally sensitive areas. ${ }^{138}$

While useful from the perspective of reaching creative solutions, the ad hoc negotiation process leaves parties with little to no frame of reference or certainty in approaching future negotiations. In particular, such an ad hoc process cannot offer guidance for valuing potential impacts to Aboriginal title. Registration of any ILUAs with the National Native Title Tribunal of Australia does not require publication of the terms of the agreements beyond a 25:4 Northern Perspectives 4. condition that has the effect of creating an entitlement for native title parties to have payments determined by reference to the amount of profits made, any income derived, or any things produced as a result of doing anything in relation to the land or waters concerned after the act is done. First Nations: Drafting Impact Benefit Agreements" (Paper prepared for the Continuing Legal Education Society of British Columbia, November 2011), cl 5.5. 
description of the area, the names of the parties, the term, and any terms respecting extinguishment of Aboriginal title where applicable. ${ }^{139}$

\section{Available Frameworks and Principles}

Based on the above principles and frameworks, we believe that there are at least three potential approaches to determining fair and reasonable compensation for impacts to Aboriginal title:

- the status quo of ad hoc, negotiated agreements backstopped by the common law;

- developing government policies or voluntary principles or guidance; or

- developing a formal legislative regime.

\section{A. Status Quo}

The first option to addressing this issue is to continue the current ad hoc approach, in which parties attempt to resolve this issue themselves without any policy or legislative framework outside of the limited guidance provided by existing case law. We believe that the current approach, without any type of policy or legislative framework, is undesirable for a number of reasons.

First, this approach is unprincipled, and leads to widely varying results that depend on what the project can bear and the negotiating skills and positions of the particular Aboriginal group and proponent, which can vary significantly. The approach not only creates the risk of unfair results on either side, but also fails to advance the goal of reconciliation amongst Aboriginal and non-Aboriginal Canadians. Unprincipled approaches that are not tied to actual impacts, loss of value, or established benefit sharing principles can exacerbate tensions and foster resentment both between Aboriginal groups and proponents, as well as neighbouring Aboriginal groups who may be impacted by a particular project to a lesser degree. ${ }^{140}$

Second, the current ad hoc approach creates significant uncertainty and deters investment in Canada. The absence of a framework makes it impossible for proponents to quantify this project cost at an early stage and can result in protracted negotiations once discussions begin, which can lead to project delay. Industry proponents need a principled approach to determine compensation where appropriate in order to determine the economics of the project and

Australia, National Native Title Tribunal, "Search Register of Indigenous Land Use Agreements," online: $<$ www.nntt.gov.au/searchRegApps/NativeTitleRegisters/Pages/Search-Register-of-IndigenousLand-Use-Agreements.aspx $>$.

140 Discrepancies in the results of negotiations with Aboriginal groups will likely become more of an issue after 1 June 2017, when the federal Extractive Sector Transparency Measures Act, SC 2014, c 39 will require proponents to disclose certain payments made to Aboriginal governments above a prescribed level. Such increased disclosure could create significant tensions amongst Aboriginal groups, as well as between Aboriginal groups and industry, if vastly different compensation arrangements are disclosed for the same or similar projects. This is likely to occur at least between similar projects, as proponents have differing approaches to structuring cash compensation and other economic opportunities in agreements, and only the cash component must be disclosed (and only then if it is above a certain prescribed level). 
alternatives at an early stage. Project proponents cannot afford, in many cases, to be subject to lengthy and inconclusive regulatory processes where delays are unpredictable and outcomes are uncertain. For certain projects, undue delays can cause the project to no longer be economically viable, requiring significant investment writeoffs and disincentives to future investment in Canada.

Third, the current approach provides little clarity as between the role of proponents in negotiating agreements with Aboriginal groups that assert strong title claims, and the role of the Crown in ensuring any required economic accommodation or compensation has been offered. Increasingly, the Crown will be required to consider how to reconcile its legal and, in the case of proven title, fiduciary obligations to Aboriginal groups, and the business negotiations being carried out between proponents on specific projects. Developing a compensation framework is an important initial step on the path toward resolving this broader issue.

Fourth, continuing the status quo will unnecessarily lead to protracted and costly litigation where agreements cannot be reached. While the courts have not yet determined this issue, it is inevitable that they will be forced to in the future. ${ }^{141}$ We believe it is better for all parties, and for the sake of reconciliation, to take a proactive approach in developing a framework that can be considered by the courts. The alternative, to leave this development entirely to the courts, could produce an unduly impractical high-level scheme resulting in even more litigation and delay, which will ultimately defer investment activity.

\section{B. Government Policy}

The second option would be for governments to develop their own policies. These policies could, of course, be broader than simply Aboriginal title and address other impacts to Aboriginal and treaty rights where compensation may be required. In developing these policies, federal, provincial, and territorial governments would need to undertake consultation processes with Aboriginal groups and industry to ensure different perspectives are considered in the relevant policy.

Policies to guide statutory decision-makers could address some or all of the following issues:

- establishing the factors that government will consider when it may be required to compensate for infringements to Aboriginal title;

- clarifying what role impact benefit agreements or other commercial arrangements between proponents and Aboriginal groups may have in compensating for impacts on Aboriginal title; and action against a third party proponent for impacting Aboriginal rights. See e.g. Saik'uz First Nation and Stellat'en First Nation v Rio Tinto Alcan Inc, 2015 BCCA 154, [2015] 12 WWR 67; Compagnie minière IOC inc (Iron Ore Company of Canada) c Uashaunnuat (Innus de Uashat et de Mani-Utenam), 2015 QCCA 2, 2015 QCCA 2 (CanLII); Ominayak v Penn West Petroleum Ltd, 2015 ABQB 342, [2015] 3 CNLR 156. 
- if government intends to rely on proponent compensation contained in impact benefit agreements or other commercial arrangements in meeting its own obligations, establishing how information about proponent compensation could be disclosed to government for this purpose while balancing the need to protect the confidentiality of sensitive commercial negotiations.

Best practices policies could address an even broader set of principles, including providing specific guidance to proponents on developing projects on lands subject to strong Aboriginal title claims or developing voluntary frameworks or dispute resolution mechanisms that parties can agree to follow.

There are advantages and disadvantages to a policy-based or voluntary approach. In terms of advantages, this approach could provide much greater certainty concerning the Crown's expectations, while at the same time maintain flexibility for different approaches and further evolution in the law. It would also provide an opportunity for all affected parties to share their varying perspectives in a less adversarial consultation process (that would precede development of any policy). It would also provide an opportunity for all affected parties to share their varying perspectives and develop practices over time, in comparison to leaving it to the courts to develop principles within the confines of a specific set of facts that may not reflect the needs of Aboriginal groups, governments, or industry.

One of the main challenges with a policy-based or voluntary approach is its development and implementation, particularly if done at the national level. There are significant regional, legal, and cultural differences between Aboriginal groups, and likely substantially varying views amongst Aboriginal groups, provincial and territorial governments, as well as industry proponents, on this complex and novel issue. Developing a single, workable approach would be very difficult and time consuming. Perhaps an alternative approach would be to commence the reform process in a particular jurisdiction, British Columbia being a logical starting point, given the prevalence of Aboriginal title claims. Such a process could potentially expand to parallel the Canadian experience in reforming expropriation law through the use of a provincial Law Reform Commission. As seen in Ontario, this subsequently resulted in the adoption of the reforms by the other provinces. This approach, regardless of the jurisdiction chosen, presents an attractive option by its limitation of the scope, and therefore complexity, of the reform process.

Even if a consultative process could achieve a common set of principles, a policy-based or voluntary approach would not provide complete certainty to Aboriginal groups, proponents, or governments, given the lack of firm compliance measures provided by a legislated approach (although in practice, policy guidance from a statutory decision-maker will generally be followed by proponents seeking to obtain favourable decisions). With respect to voluntary measures or best practices, there is also a risk of limited uptake unless the process meets the needs of the parties. In addition, these processes will provide no recourse other than the courts in the event that the parties cannot reach an agreement, or do not agree to any voluntary dispute mechanisms that may be developed. That said, policy guidance and best practices could still be persuasive to the courts if asked to consider how to quantify fair and reasonable compensation for infringements of Aboriginal title. 


\section{Legislative Regime}

The third option would be to develop a formal legislative scheme, similar to Australia. The attractive feature of such a scheme is the significant increase in certainty and structure that such a regime would bring, in contrast to an approach based on voluntary principles or guidance. It could also provide for more expeditious resolution of disagreements through dispute resolution or mediation rather than through the normal court process. Such a regime could be mandatory or allow for parties to opt-in.

A mandatory scheme would have the advantage of establishing a clear process and levelplaying field for all parties within the relevant jurisdiction. However, we anticipate it would not be feasible to obtain the consensus needed to develop a mandatory scheme. There would be little appetite amongst governments, and rightly so, to impose a top-down solution in such a contentious area that engages constitutional rights, and would undoubtedly be subject to judicial challenge. Even if consensus could be reached, implementing such a scheme would be a much more laborious, time-consuming process, and future amendments would entail significant time and effort.

An alternative could be the development of an opt-in regime such as the FNLMA. Aboriginal groups could voluntarily opt-in to a framework developed by government. If an Aboriginal group opted-in, any proponent developing a project within the defined territory of the Aboriginal group could either be compelled to abide by the framework or have a similar ability to opt-in. This option could include access to alternative dispute resolution which would provide a more expeditious way to resolve disputes and avoid protracted litigation.

\section{Conclusions}

Developing principles of compensation for impacts to Aboriginal title is not an easy task. The challenge of reconciling widely divergent views on issues tied to a deeply political and historical context should not be understated. Any proposed policies or frameworks that do not respect this context will undoubtedly face significant challenge.

Nevertheless, this article posits that the current ad hoc approach is not sustainable, and that the law is capable of addressing similar challenges in different contexts, including valuing seemingly invaluable rights and balancing individual or group rights with broader public interests. The frameworks described in this article suggest that a well-considered regime that balances respect for the unique nature and importance of Aboriginal title rights with the need for greater clarity for the benefit of all parties is possible and desirable.

In order to reflect both common law and Aboriginal perspectives, we believe that any framework should consider the following principles for determining compensation:

- the cost of equivalent reinstatement;

- the market value of the estate or interest being utilized;

- the length of time that the estate or interest will be utilized or impacted; 
- the ability of the Aboriginal group to still make use of the land;

- the replacement of any improvements on the land being utilized (where it is established Aboriginal title and the value of those improvements would be lost);

- $\quad$ any disturbance caused by the use; and

- the adverse effects on any cultural or other special value of the land.

In addition, we believe any framework should consider the respective roles of the Crown and proponents in delivering compensation for impacts on Aboriginal title lands. The need to reconcile the Crown's obligations to Aboriginal groups with the business negotiations being carried out among proponents on specific projects will increasingly be a pressing issue, particularly with the heightened emphasis on consent arising from Tsilhqot'in and the concepts of FPIC under UNDRIP.

In our view, a government-led policy approach within a specific jurisdiction is the most pragmatic approach to beginning to address these issues. Regardless of the process chosen, all options identified in this article require an extensive and deliberate reform process. This is not an area where governments can, or should, unilaterally impose their preferred solution. Instead, the development of such a framework would require significant consultation with Aboriginal groups, industry, and government officials to develop a workable approach that appropriately balances various interests, and acknowledges the unique considerations associated with Aboriginal title while maintaining the honour of the Crown. 